\title{
Pengaruh Self-Control terhadap Perilaku Merokok Mahasiswa selama Pandemi COVID-19
}

\section{Gita Kanya Paramitha*, Stephani Raihana Hamdan}

Prodi Ilmu Psikologi, Fakultas Psikologi, Universitas Islam Bandung, Indonesia.

pgitakanya@gmail.com, stephanihamdan@gmail.com

\begin{abstract}
The Covid-19 pandemic requires people to maintain physical distance (physical distancing) and social distancing (social distancing) to reduce the spread of the Covid-19 virus. Selfcontrol is a person's ability to be able to restrain himself and set himself up for better things when faced with temptations. Smoking activity can be influenced by various factors such as self-control as an internal factor. The purpose of this study was to determine the effect of self-control on student smoking behavior during the covid-19 pandemic. The method used in this research is correlational with the sampling technique using purposive sampling with the number of respondents being 144 people. The self-control measurement tool uses the Tangney Self-Control Scale (SCS) and the smoking behavior variable uses a measuring tool made by the Associated Counseling Professional USA (Smoking Assessment Questionnaire) which was adapted by (Stephani Raihana Hamdan, 2013). The results showed that there was a significant effect of self-control variables on smoking behavior with $\mathrm{p}=0.000 \mathrm{t}=-0.566$
\end{abstract}

Keywords: self-control, smoking, COVID-19.

\begin{abstract}
Abstrak. Pandemi Covid-19 mengharuskan masyarakat menjaga jarak fisik (physical distancing) dan jarak sosial (social distancing) untuk mengurangi penyebaran virus Covid-19. Pengendalian diri merupakan kemampuan seseorang agar dapat menahan diri dan menetapkan diri ke hal yang lebih baik saat dipertemukan dalam godaan-godaan. Aktivitas merokok dapat dipengaruhi oleh berbagai faktor seperti pengendalian diri sebagai faktor internal. Tujuan dari penelitian ini adalah mengetahui pengaruh self-control dengan perilaku merokok mahasiswa selama pandemi covid-19. Metode yang digunakan dalam penelitian ini korelasional dengan teknik sampling menggunakan purposive sampling dengan jumlah responden yaitu 144 orang. Alat ukur Self-Control menggunakan Tangney Self-Control Scale (SCS) dan variabel perilaku merokok menggunakan alat ukur yang dibuat oleh Associated Counseling Professional USA (Smoking Assessment Questionnaire) yang diadaptasi oleh (Stephani Raihana Hamdan, 2013). Hasil penelitian menunjukkan bahwa terdapat pengaruh signifikan variabel pengendalian diri terhadap perilaku merokok dengan $\mathrm{p}=0,000 \mathrm{t}=-0,566$
\end{abstract}

Kata Kunci: self-control, merokok, COVID-19. 


\section{A. Pendahuluan}

Perilaku merokok bukanlah hal yang asing karena merokok tidak memandang usia, status sosial, dan ekonomi. Rokok merupakan produk tembakau yang berpotensi menjadi penyebab masalah kesehatan yang penting di Indonesia. Merokok merupakan masalah sosial yang sulit dipecahkan karena banyaknya dampak buruk, akan tetapi merokok adalah kegiatan yang diminati oleh berbagai kalangan usia. Salah satu provinsi dengan tingkat pengguna rokok terbesar di Indonesia adalah Provinsi Jawa Barat yang dimana terjadi peningkatan jumlah perokok dari tahun ke tahun yang tercatat pada tahun 2018 dengan proporsi penduduk yang merokok lebih dari usia sepuluh tahun sebesar $27,1 \%$ yang mana angka tersebut berada diatas dari rata-rata proporsi pengguna rokok di Indonesia. (Riskesdas, 2018).

Menurut Hamdan (2013) perilaku merokok adalah perilaku menghisap asap yang mengandung zat adiktif nikotin kemudian menghembuskannya kembali keluar yang merupakan perilaku adiktif dimana terbentuk melalui proses pembentukan dan mengalami penguatan baik oleh kebiasaan diri, sikap positif terkait rokok maupun adanya dukungan lingkungan untuk merokok serta lemahnya keinginan untuk berhenti merokok

Pandemi Covid-19 yang sudah terjadi pada 215 negara di dunia, menjadi sebuah tantangan bagi suatu lembaga pendidikan terutama Perguruan Tinggi, sebagai tindakan perlawanan terhadap virus ini, pemerintah memberikan kebijakan pelarangan untuk berkumpul, menjaga jarak fisik (physical distancing) dan pembatasan sosial (social distancing), Lewat Kementerian Pendidikan dan Kebudayaan (Kemendikbud), Pemerintah memberikan larangan untuk melakukan perkuliahan secara konvensional (tatap muka) dan memberikan kebijakan untuk melakukan kegiatan perkuliahan atau kegiatan belajar mengajar (KBM) secara dalam jaringan (daring) bagi perguruan tinggi melalui Surat Edaran Kemendikbud Dikti No. 1 tahun 2020 (Kemendikbud, 2020).

Seiring dengan diterapkannya peraturan dan banyaknya dampak dari merokok, banyak yang tetap melakukan perilaku merokok. Mahasiswa yang sebelum adanya peraturan untuk school from home kegiatan merokoknya terbatas rokok sekarang berada pada situasi berbeda dimana aktivitas mayoritas berada di rumah, dimana lingkungan perumahan tidak tercakup dalam kawasan tanpa rokok. Seperti halnya dengan mahasiswa, secara umum ketika seseorang memiliki self-control yang rendah maka hal tersebut akan mengacu pada ketidakmampuan seseorang untuk menahan diri dalam melakukan suatu hal dan tidak dapat memikirkan akibat atas hal tersebut dalam jangka panjang, sebaliknya seseorang yang memiliki self-control yang besar maka bisa menahan diri terhadap suatu hal yang merugikan dengan dapat menahan diri dari hal-hal yang berbahaya dengan meninjau akibatnya dalam jangka panjang (Ursia, 2013). Seseorang yang memiliki kontrol yang rendah pada dirinya tidak dapat mengatur dan memantapkan arah perilakunya, sehingga dapat ditaksirkan seseorang dengan tingkat kontrol diriyang rendah dapat bertindak dan berperilaku lebih terhadap segala hal yang membahagiakan dirinya (Angelina, 2013). Hal ini sejalan dengan teori self-control dari Tangney, et al (2004) yang mengatakan bahwa pengendalian diri (self-control) adalah kemampuan individuagar bisa melebihi atau menggantikan respon yang terdapat pada diri agar menghadang sifat-sifat yang tidak diharapkan timbul sebagai wujud respon dari suatu keadaan. Lebih lanjut Tangney et al menjelaskan bahwa karakteristik kontrol diri adalah dapat mengendalikan pikiran, emosi, dorongan, dan mengatur performa serta dapat menghentikan kebiasaan. (Tangney et al, 2004).

Pada self-control terdapat aspek-aspek yang menguatkan perilaku tersebut antara lain self-discipline yaitu mahasiswa tidak mampu memfokuskan diri saat melakukan tugas. Sedangkan mahasiswa dengan self-discipline mampu menahan dirinya dari hal-hal lain yang dapat mengganggu konsentrasinya. Lalu terdapat aspek Deliberate/nonimpulsivedimana mahasiswa melakukan sesuatu tidak dengan pertimbangan tertentu, tidak hati-hati, dan tergesa-gesa. Ketika sedang bekerja, ia cenderung mudah teralihkan. Individu yang tergolong nonimpulsive mampu bersifat tenang dalam mengambil keputusan dan bertindak. Terdapat aspek Healthy habits dimana mahasiswa tidak dapat mengatur pola perilaku menjadi kebiasaan yang menyehatkan. Mahasiswatidak dapat menolak sesuatu yang dapat menimbulkan dampak buruk bagi dirinya karena hal tersebut menyenangkan. Selanjutnya 
terdapat aspek work ethic, dimana mahasiswa tidak mampu menyelesaikan pekerjaan dengan baik tanpa dipengaruhi oleh hal-hal di luar tugasnya yang bersifat menyenangkan. Terakhir yaitu aspek reliability dimana mahasiswa tidak dapat secara konsisten mengatur perilakunya untuk mewujudkan setiap perencanaannya.

Berdasarkan penelitian yang dilakukan oleh (Fauzan, 2018) menunjukkan bahwa terdapat hubungan signifikan antara self-control dan peer conformity dengan perilaku merokok. Artinya, kurangnya kemampuan mengendalikan diri dan konformitas negatif teman sebaya, merupakan faktor yang berkontribusi terhadap timbulnya perilaku merokok. Oleh karena itu peneliti ingin meneliti pengaruh antara kedua variabel.

Berdasarkan latar belakang yang telah diuraikan, maka perumusan masalah dalam penelitian ini sebagai berikut: "Seberapa besar pengaruh self control dengan perilaku merokok mahasiswa selama pandemi COVID-19?". Selanjutnya, tujuan dalam penelitian ini diuraikan dalam pokok-pokok sbb.

1. Mengetahui seberapa besar pengaruh self control dan persepsi kawasan tanpa rokok dengan perilaku merokok mahasiswa selama pandemi COVID-19 baik secara parsial maupun simultan

2. Mengetahui gambaran self control mahasiswa

3. Mengetahui perilaku merokok mahasiswa selama pandemi COVID-19

\section{B. Metodologi Penelitian}

Populasi penelitian ini adalah seluruh mahasiswa di Kota Bandung yang merokok, dengan jumlah minimal sampel 96.

1. Menggunakan teknik purposive sampling dengan kriteria:

2. Mahasiswa Jenjang S1

3. Berdomisili di Kota Bandung

4. Mahasiswa aktif Kota Bandung yang mempunyai kebiasaan merokok (sudah menjadi perokok tetap atau rutin minimal 2 tahun terakhir)

Teknik pengumpulan data yang digunakan dalam penelitian ini adalah kuesioner. Adapun teknik analisis data menggunakan uji regresi dan analisis koefisien determinasi. Menggunakan Teori Self-Control Tangney (2004) yang mencakup 4 aspek diantaranya

1. Self-discipline

Yaitu mengacu pada kemampuan individu dalam melakukan disiplin diri. Hal ini berarti individu mampu memfokuskan diri saat melakukan tugas. Individu dengan selfdiscipline mampu menahan dirinya dari hal-hal lain yang dapat mengganggu konsentrasinya

2. Deliberate

Yaitu kecenderungan individu untuk melakukan sesuatu dengan pertimbangan tertentu, bersifat hati-hati, dan tidak tergesa-gesa. Ketika individu sedang bekerja, ia cenderung tidak mudah teralihkan. Individu yang tergolong nonimpulsive mampu bersifat tenang dalam mengambil keputusan dan bertindak.

3. Healthy habits

Yaitu kemampuan mengatur pola perilaku menjadi kebiasaan yang menyehatkan bagi individu. Oleh karena itu, individu dengan healthy habits akan menolak sesuatu yang dapat menimbulkan dampak buruk bagi dirinya meskipun hal tersebut menyenangkan. Individu dengan healthy habits akan mengutamakan hal-hal yang memberikan dampak positif bagi dirinya meski dampak tersebut tidak diterima secara langsung.

4. Work ethic

Yang berkaitan dengan penilaian individu terhadap regulasi diri mereka di dalam layanan etika kerja. Individu mampu menyelesaikan pekerjaan dengan baik tanpa dipengaruhi oleh hal-hal di luar tugasnya meskipun hal tersebut bersifat menyenangkan. Individu dengan work ethic mampu memberikan perhatiannya pada pekerjaan yang sedang dilakukan.

5. Reliability

Yaitu dimensi yang terkait dengan penilaian individu terhadap kemampuan dirinya dalam pelaksanaan rancangan jangka panjang untuk pencapaian tertentu. Individu ini secara konsisten akan mengatur perilakunya untuk mewujudkan setiap perencanaannya 
Untuk Perilaku Merokok menggunakan Teori Hamdan (2013) dengan aspek:

6. Riwayat perilaku merokok

Yaitu adanya gambaran proses mencoba merokok pertama kali dan pembentukan kebiasaan rutin merokok yang dikuatkan oleh pemikiran dan dukungan/contoh orang disekitarnya.

7. Konsumsi Rokok

Yaitu adanya gambaran kebiasaan merokok rutin baik dalam jumlah batang rokok, kebiasaan merokok baik setelah bangun pagi, situasi dan kondisi yang menguatkan atau melemahkan untuk merokok dan dana yang disiapkan untuk merokok.

8. Pandangan mengenai Rokok

Yaitu gambaran positif melalui seberapa penting merokok baginya, seberapa besar manfaat dan kerugian yang dialami akibat merokok, sikap orang terdekat dan pengaruhnya pada kebiasaan merokok, dan faktor yang menguatkan diri untuk merokok.

9. Keinginan berhenti merokok

Yaitu gambaran seberapa lemah keinginan berhenti merokok, pengalaman gagal berhenti merokok, kondisi orang terdekat yang mendukung atau menghambat untuk berhenti merokok, faktor penguat untuk tetap merokok dan seberapa kuat kontrol diri untuk tidak merokok (Hamdan, 2013).

Alat ukur yang digunakan yaitu SCS (Self Control Scale) oleh Tangney yang telah diadaptasi kedalam bahasa Indonesia dan alat ukur yang telah diadaptasi oleh Hamdan (2013). Alat ukur ini dibuat oleh Associated Counseling Professional USA (Smoking Assessment Questionnaire).

\section{Hasil Penelitian dan Pembahasan Pengaruh Self-Control (X) dengan Perilaku Merokok (Y)}

Tabel 1. Pengaruh Self-Control terhadap Perilaku Merokok

\begin{tabular}{|l|l|l|l|l|l|}
\hline Variabel & $t_{\text {hitung }}$ & $t_{\text {tabel }}$ & Keputusan & Besaran pengaruh & Koefisien Determinasi \\
\hline X dan Y & $-5,178$ & 1,977 & Ho ditolak & $-0,566$ & $45,45 \%$ \\
\hline
\end{tabular}

Berdasarkan hasil pengolahan tabel di atas, dapat terlihat bahwa t-hitung yang dihasilkan SelfControl adalah sebesar -5,178 dengan nilai absolut 5,178 dan nilai sig. 0,000. Maka hasil tersebut menunjukkan bahwa t-hitung > t-tabel, yaitu 5,178 >1,977 dan tingkat signifikansi sebesar $0,000<0,05$ maka dinyatakan Ho ditolak. Sehingga dapat disimpulkan bahwa SelfControl berpengaruh terhadap perilaku merokok. Perilaku merokok 45,45\% dipengaruhi oleh self-control dan sisanya oleh variabel lain yang tidak diteliti. 


\section{Hasil Perhitungan Sumbangan Efektif Aspek Self-Control}

Tabel 2. Sumbangan Efektif Self-Control

\begin{tabular}{ccc}
\hline \multirow{2}{*}{ No } & Aspek & Nilai \\
\hline \multirow{2}{*}{1} & Self-Discipline & $24,12 \%$ \\
\hline 2 & Deliberate & $33,25 \%$ \\
\hline 3 & Healthy Habits & $17,22 \%$ \\
\hline 4 & Work Ethics & $13,81 \%$ \\
\hline 5 & Reliability & $11,60 \%$ \\
\hline & & \\
\hline & Total & $100 \%$
\end{tabular}

Berdasarkan tabel diatas diperoleh hasil aspek self-discipline sebesar 24,12\%, kemudian aspek deliberate sebesar $33,25 \%$, aspek healthy habits sebesar $17,22 \%$, aspek work ethics sebesar $13,81 \%$, aspek reliability sebesar $11,60 \%$. Hasil tersebut menunjukkan bahwa self discipline memberikan sumbangan efektif sebesar $33,25 \%$,deliberate sebesar $33,25 \%$, healthy habits sebesar 17,22\%, work ethics sebesar 13,81\%, reliability sebesar 11,60\% terhadap Self-Control. Data Kuantitatif Perilaku Merokok

Tabel 3. Data Perilaku Merokok

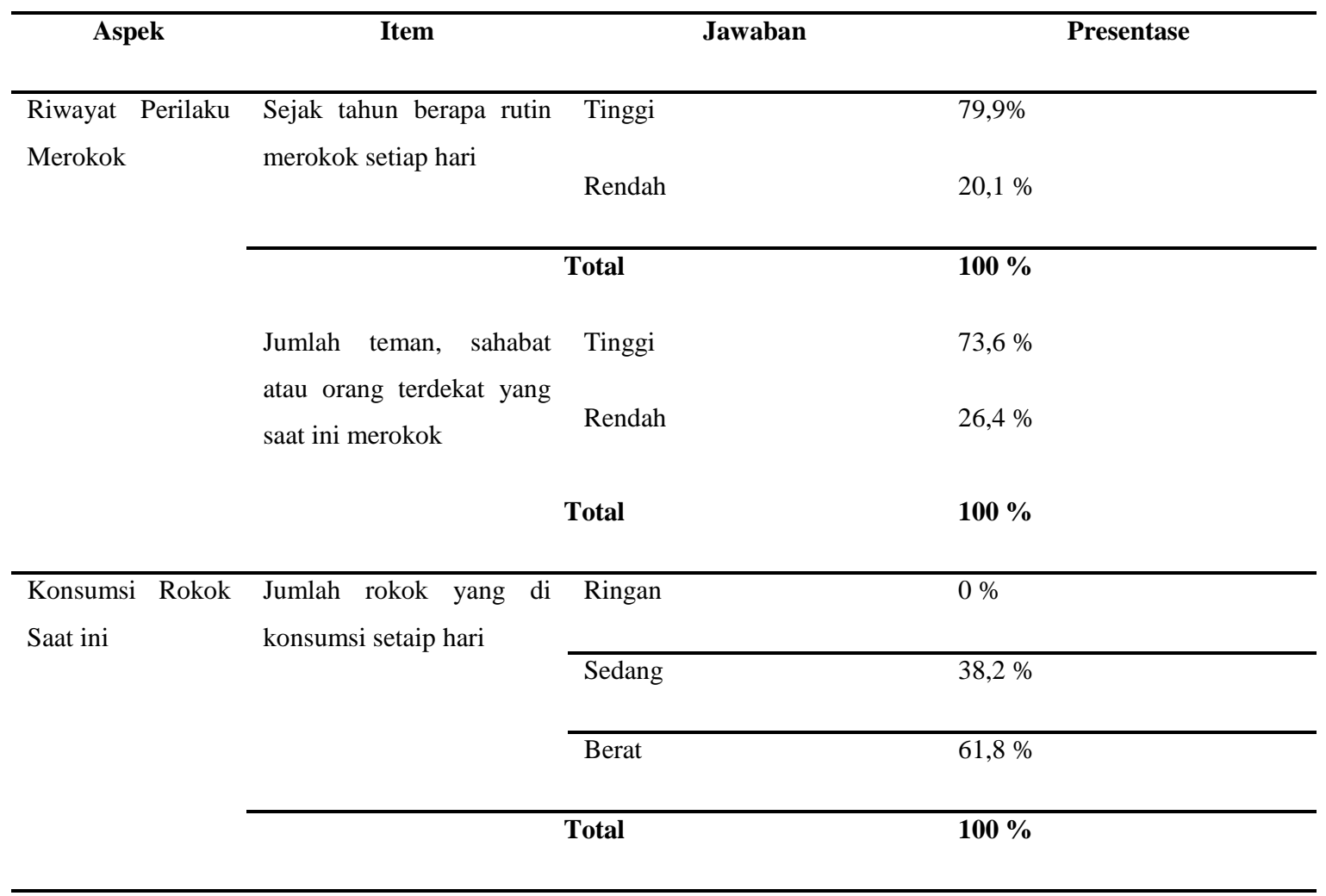




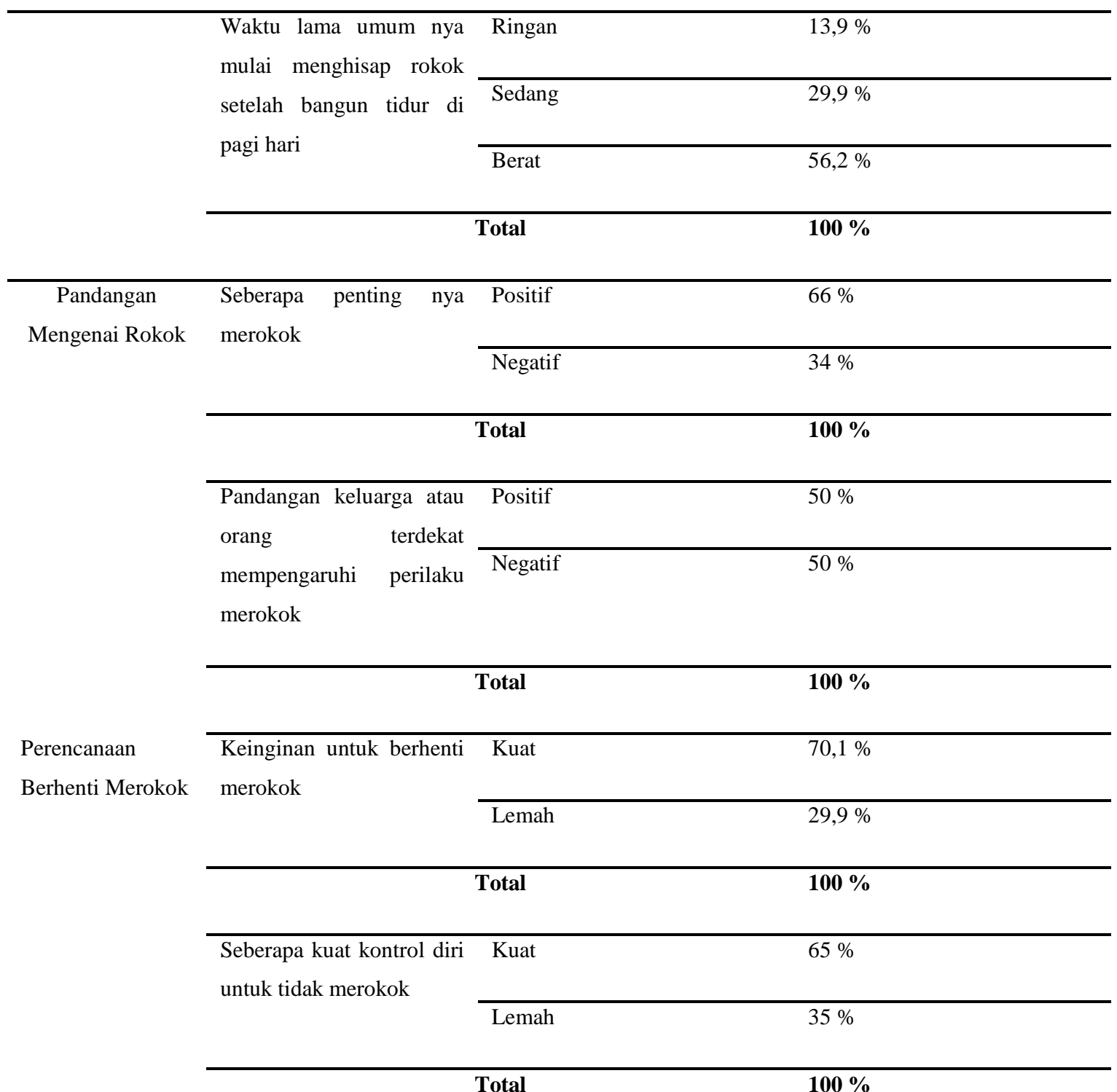

Berdasarkan tabel diatas mahasiswa untuk aspek riwayat perilaku merokok dengan kategori tinggi untuk lamanya sejak mulai merokok yaitu sebesar $79,9 \%$, dan jumlah teman, sahabat, atau orang terdekat yang saat ini merokok berada pada kategori tinggi yaitu sebesar $73,6 \%$. Pada aspek konsumsi rokok saat ini, untuk jumlah rokok yang dikonsumsi setiap hari paling banyak pada kategori berat sebesar $61,8 \%$, untuk waktu mulai menghisap rokok setelah bangun di pagi hari paling tinggi di kategori berat yaitu sebesar $56,2 \%$. Pada aspek pandangan mengenai rokok untuk seberapa pentingya merokok paling tinggi yaitu positif sebesar $66 \%$, dan pandangan keluarga mempengaruhi perilaku merokok sama tingginya antara positif dan negatif. Terakhir pada aspek perencanaan berhenti merokok, untuk keinginan berhenti merokok paling tinggi di kategori kuat sebesar 70,1\% dan seberapa kuat kontrol diri untuk tidak merokok paling tinggi kategori kuat sebesar $65 \%$.

Menurut Ursia (2013) Secara umum ketika seseorang memiliki self-control yang rendah maka hal tersebut akan mengacu pada ketidakmampuan untuk menahan diri dalam melakukan suatu hal dan tidak dapat memikirkan akibat atas hal tersebut dalam jangka panjang, hal ini terlihat ketika mahasiswa memiliki keinginan mereka tidak mampu menahan diri untuk tidak melakukan hal tersebut dan tidak dapat memikirkan dampak negatif dari hal tersebut secara jangka panjang, seperti halnya mahasiswa perokok yang tidak mampu menahan diri untuk tidak merokok dan tidak dapat memikirkan efek jangka panjang dari perilaku merokok tersebut, sehingga mereka akan tetap melakukannya walaupun itu 
merupakan perilaku yang berisiko.

Hal tersebut sejalan dengan hasil penelitian yang dilakukan oleh (Runtukahu, Sinolungan, dan Opod, 2015) yang menunjukkan bahwa terdapat hubungan yang signifikan antara self-control dengan perilaku merokok karena kontrol diri sebagai proses yang menjadikan mahasiswa sebagai agen utama dirinya sendiri dalam memandu, mengarahkan dan mengatur perilaku utamanya yang dapat membawa ke arah konsekuensi positif, sehingga disini mahasiswa perokok tidak dapat mengarahkan dan mengatur perilakunya sendiri kearah konsekuensi positif dikarenakan merokok sendiri merupakan perilaku yang mendatangkan konsekuensi negatif.

Tangney (2004) mendefinisikan self-control sebagai kemampuan individu agar bisa melebihi atau menggantikan respon yang terdapat pada diri agar menghadang sifat-sifat yang tidak diharapkan timbul sebagai wujud respon dari suatu keadaan. Impulsivitas dipandang sebagai predisposisi terhadap reaksi yang cepat dan tidak terencana terhadap rangsangan internal maupun eksternal tanpa memperhatikan konsekuensi negatif dari reaksi yang ditampilkan terhadap individu yang impulsif atau orang lain., karakteristik kontrol diri adalah dapat mengendalikan pikiran, emosi, dorongan, dan mengatur performa serta dapat menghentikan kebiasaan

Hal tersebut dipengaruhi oleh beberapa aspek self-control yang memperkuat perilaku mahasiswa, diantaranya aspek self-discipline yaitu mahasiswa sulit memfokuskan diri saat melakukan tugas. Mahasiswa sulit untuk tidak terganggu konsentrasinya dengan perilaku merokok. Sedangkan mahasiswa dengan self-discipline mampu menahan dirinya dari hal-hal lain yang dapat mengganggu konsentrasinya. Aspek Deliberate/nonimpulsive dimana mahasiswa melakukan sesuatu tidak dengan pertimbangan tertentu, tidak hati-hati, dan tergesa-gesa. Dimana melakukan perilaku merokok tanpa pertimbangan terlebih dahulu. Ketika sedang bekerja, ia cenderung mudah teralihkan. Individu yang tergolong nonimpulsive mampu bersifat tenang dalam mengambil keputusan dan bertindak. Mahasiswa yang perokok akan lebih impulsif. Terdapat aspek Healthy habitsdimana mahasiswa tidak dapat mengatur pola perilaku menjadi kebiasaan yang menyehatkan. Mahasiswatidak dapat menolak sesuatu yang dapat menimbulkan dampak buruk bagi dirinya karena hal tersebut menyenangkan. Selanjutnya terdapat aspek work ethic, dimana mahasiswa tidak mampu menyelesaikan pekerjaan dengan baik tanpa dipengaruhi oleh hal-hal di luar tugasnya yang bersifat menyenangkan. Terakhir yaitu aspek reliability dimana mahasiswa tidak dapat secara konsisten mengatur perilakunya untuk mewujudkan setiap perencanaannya.

Dari masing-masing aspek tersebut, diperoleh sumbangan efektif mengenai hasil aspek self-discipline sebesar 24,12\%, kemudian aspek deliberate sebesar 33,25\%, aspek healthy habits sebesar $17,22 \%$, aspek work ethics sebesar 13,81\%, aspek reliability sebesar $11,60 \%$. Artinya, aspek yang mempengaruhi dan memberikan hasil sumbangan efektif paling besar adalah aspek deliberate sebesar $33,25 \%$ yang dimana mahasiswa melakukan sesuatu tidak dengan pertimbangan tertentu, tidak hati-hati, dan tergesa-gesa. Mahasiswa cenderung tidak mempertimbangkan dampak serta konsekuensi dari perilaku merokoknya bagi diri mereka sendiri maupun orang disekitarnya yang juga dirugikan, tidak bersikap hati hati akan perilakunya serta tergesa gesa dalam mengambil keputusan untuk merokok walaupun kemungkinan mereka mengetahui konsekuensinya.

Dapat disimpulkan bahwa perilaku yang ditampilkan mahasiswa itu tidak didasari dengan pertimbangan matang sehingga memiliki kecenderungan berperilaku tanpa pemikiran yang matang.

\section{Kesimpulan}

Berdasarkan pembahasan dalam penelitian ini, peneliti menyimpulkan beberapa hasil penelitian sebagai berikut:

1. Terdapat pengaruh negatif dan signifikan antara variabel self-control terhadap perilaku merokok pada mahasiswa Kota Bandung.

2. 87y Gambaran self-control secara umum dapat dikatakan rendah sumbangan efektif sebesar $45,45 \%$. Sedangkan, aspek self-control yang paling tinggi adalah aspek 
deliberate dengan memberikan sumbangan efektif sebesar 33,25\%.

3. Perilaku merokok yang terjadi pada mahasiswa dapat dikatakan tinggi. Berdasarkan hasil data dimana jumlah berapa batangnya mereka merokok setiap hari, riwayat sejak tahun berapa merokok, jumlah teman, sahabat dan orang terdekat yang merokok serta aspek lain yang menyebabkannya.

\section{Acknowledge}

Ucapan terima kasih saya sampaikan kepada Allah SWT, kedua orang tua saya, pembimbing serta pihak pihak yang tidak bisa saya sampaikan satu per satu yang telah turut serta dalam pengerjaan penelitian ini hingga bisa sampai pada tahap ini.

\section{Daftar Pustaka}

[1] Angelina, D., \& Matulessy, A. (2013). Pola Asuh Otoriter, Kontrol Diri Dan Perilaku Seks Bebas Remaja SMK. Persona, Jurnal Psikologi Indonesia, 2(2), 173-182. doi: https://doi.org/10.30996/persona.v2i2.106

[2] Fauzan, Firman, \& Daharnis. (2018). Relationship between self-control and peer conformity with smoking behavior. Dipresentasikan dalam International Conferences on Educational, Social Sciences and Technology (pp. 233239). Universitas Negeri Padang. icesst-2018- 34.pdf (gci.or.id)

[3] Hamdan, Stephani R. Pengukuran dan Intervensi Perilaku Merokok Menggunakan Pendekatan Implisit. Tesis Magister Profesi Psikologi Universitas Padjajaran.

[4] Runtukahu, G., Sinolungan, J., \& Opod, H. (2015). HUBUNGAN KONTROL DIRI DENGAN PERILAKU MEROKOK KALANGAN REMAJA DI SMKN 1 BITUNG. Jurnal e-Biomedik (eBm), 3(1), 84-92. doi: https://doi.org/10.35790/ebm.3.1.2015.6611

[5] Tangney, J., Baumeister, R., \& Boone, A. (2004). High Self-Control Predicts Good Adjustment, Less Pathology, Better Grades, and Interpersonal Grades. Journal of Personality, 72(2), 